\title{
Long Non-Coding RNA Cancer Susceptibility 9 (CASC9) Up-Regulates the Expression of ERBB2 by Inhibiting miR-193a-5p in Colorectal Cancer [Retraction]
}

Ding Y, Li X, Zhang Y, Zhang J. Cancer Manag Res. 2020;12:1281-1292.

The Editor and Publisher of Cancer Management and Research wish to retract the published article.

The journal was notified of discrepancies in Table 2 for the Depth of invasion numbers reported. The total number of cases was reported as 70, however the number of cases recorded for the Relative CASC 9 Expression ( $\mathrm{n}=29$ (Low); $\mathrm{n}=41$ (High)) was inconsistent with the grouping values provided $(\mathrm{n}=34$ (Low); $\mathrm{n}=36(\mathrm{High})$ ). The authors were unable to provide a satisfactory explanation for this discrepancy and were also unable to provide satisfactory raw data for the study reported.
The editor determined the findings of the study were no longer valid and requested for the article to be retracted.

The authors wish to apologise for this error.

Our decision-making was informed by our policy on publishing ethics and integrity and the COPE guidelines on retraction.

The retracted article will remain online to maintain the scholarly record, but it will be digitally watermarked on each page as "Retracted".

\section{Publish your work in this journal}

Cancer Management and Research is an international, peer-reviewed open access journal focusing on cancer research and the optimal use of preventative and integrated treatment interventions to achieve improved outcomes, enhanced survival and quality of life for the cancer patient.
The manuscript management system is completely online and includes a very quick and fair peer-review system, which is all easy to use. Visit http://www.dovepress.com/testimonials.php to read real quotes from published authors. 